\title{
Determination of ethanol in dietetic supplements syrups type
}

\author{
Marina Peruničić Lučićc ${ }^{*}$, \\ Zorica Basić ${ }^{1}$ \\ Brižita Đorđević2, \\ Bojana Vidovićz \\ ${ }^{1}$ Medical Military Academy, Crnotravska 17 , \\ 11000 Belgrade, Serbia \\ ${ }^{2}$ Faculty of Pharmacy - University of Belgrade \\ Vojvode Stepe 450, 11000 Belgrade, Serbia \\ Rad primljen: 04.06.2015. \\ Corresponding author: \\ Marina Peruničić Lučić \\ Medical Military Academy 11000 Belgrade, Serbia \\ e-mail: marina.perunicic@gmail.com \\ tel. $063 / 85-86-872$
}

\begin{abstract}
Dietary supplements are intended to supplement normal nutrition and they are concentrated sources of vitamins, minerals and other substances with nutritional and physiological effects. Because of large use of dietary supplements, which often contain ethanol, we have to educate health workers, as well as consumers in this area, and hope that the use of dietary supplements will become safe, controlled and rational.

Ethanol is used for extraction, and it is also important as a stabilizer in a significant number of dietary products in the form of syrup. Because of that, a lot of dietary products contain ethanol, and often it is not declared. One more problem is the fact that users who read the declaration cannot conclude that ethanol is present in these products. Also, some of these syrups can be ordered through the internet without information of percentage of ethanol, which is worrying. Besides that, some syrup contains concentrations of ethanol in the amount that is the same as is in spirit drinks. We used liquid chromatography with a refractometer detector and carbohydrate column, temperature $90^{\circ} \mathrm{C}$, for the detection of ethanol in a dietary supplements syrup-type between 2007 to 2016. Then we ordered concentration of ethanol by external standard method. Content of ethanol was from $<0,05 \%$ to $28,35 \%$. We analyzed 76 syrups and $67 \%$ of them did not have ethanol on a declaration. $8 \%$ of syrups with ethanol declaration did not have the same amount of ethanol as remarked on the declaration. Also, 66\% of all tested syrups had alcohol higher than 1,2\% [12].

Syrups are traditionally used in our country, and often used in combination with some drugs, and that can lead to different adverse reaction.
\end{abstract}

Keywords: ethanol, HPLC, supplements, declaration

\section{INTRODUCTION}

Making spirits dates back 7000 years ago-from Asian nations (China), and then Egypt, Ancient Greece, the Roman Empire. Ethanol is used as a solvent in the pharmaceutical and cosmetic preparation (perfumes, aftershave lotions, water for rinsing the mouth...), in the industry, as well as an antidote for methanol and ethylene glycol poisoning. Alcoholic drinks have been produced and consumed by human for thousand years and have played an important role in religion, supplying nutrition and energy; providing medicinal, antiseptic and analgesic benefits; increasing the pleasure of eating; providing pharmacological benefits and generally enhancing the quality and pleasures of life [7]. Term "alcohol" was created by Paracelsus, a doctor and chemist (1493 - 1541), by using the Arabic word which means very fine powder (Walter P. 1982). Ethanol can be used as an extraction solvent in herbal pharmaceutical products. In this case, the use of ethanol is necessary for extraction of some constituents that are important for efficacy. The adverse reactions to alcohol are individual so it can be very different from person to person.
Many factors are responsible for the adverse effects of ethanol, such as age, gender, nutritional status, psychological state, and especially the initial amounts of alcohol. It should be pointed out that ethanol's effects on the immune system are rather complex. Acute exposure to ethanol in vivo suppresses various inflammatory responses (e.g., leukocyte recruitment and endothelial cell activation) (Saeed et al. 2004) [15]. Allergy symptoms include palpitations, nasal congestion, headache, low blood pressure and abdominal pain. Because of all these symptoms it is very important to detect and warn about the content of ethanol in the products [4]. A moderate dose of alcohol had no effect on motor performance [1], but small amounts of alcohol can potentiate the effects of many of drugs the resulting hazard to patients is likely to be considerable. Using alcohol would indicate significant depression, with an inability to perform complicated tasks such as driving or operating machinery [5].

We used liquid chromatography for determination of ethanol and retain analyze_molecules on the carbohydrate column based on differences in the exchange equilibrium between the various sample 
ions and the effluent ion [6]. In relation to retention time, and compared pick area of the sample to area of standards, we can find out the concentration of ethanol. Detection is based on the change of the refractive index. It is possible to measure differences in index of refraction to 1 part in $10^{6}$ or even better. High sensitivity depends on the mobile phase and the temperature $[2,14]$. We validated this method in our laboratory. Selectivity factor (a), which is a measure for separation of the two components and it is believed that the $a>>1$ achieved a satisfactory separation of the tested components [3].

The WHO (World Health Organization) proposes to limit the ethanol amount in OTC (over-the-counter) products to less than $0,5 \%$ for children less than 6 years old, less than 5\% for children $6-12$ years old and less than $10 \%$ for children over 12 years. However, these limits do not take into consideration the actual dose given [11]. The FDA (Food and Drug Administration) also recommends not including ethanol in medicinal products intended for use in children. But if necessary, the amount of ethanol in OTC liquid preparations should not be more than $5 \%$ ethanol $[10,13]$. In Serbia we have only one limit for declaration of ethanol up to 1,2 \% [12].

\section{MATERIAL AND METHODS}

Gas chromatography (GC) and high-performance liquid chromatography (HPLC) are common techniques to identify and quantify components of ethanol. Infrared spectroscopy (IR) is used for quality assurance of ethanol. Many extensive researches for ethanol analysis with HPLC have done (Sen et al., 1995, Yarita et al., 2002, Alcázar et al., 2006) [9]. Our choice was high performance liquid chromatography.

We analyzed 76 syrups and $69,74 \%$ of them are herbal mixtures; $14,47 \%$ are vitamin type; 5,26\% marshmallow (Althaea radix); 3,95\% are primrose (Primula veris); 2,63 \% ivy (Hederae helicis folium); 2,63 \% plantain (Plantago lanceolata); $1,32 \%$ medical type.

Calibrations of ethanol were done in five points at concentration of $0.05 \% ; 0.1 \% ; 0.5 \% ; 1.0 \%$ and $2.0 \%$. The working solution was $10 \%$ ethanol. Absolute ethanol needs to be rapidly dissolved in a small amount of water to avoid evaporation. Solutions can be shaken, but not heated to improve solubility. The correlation coefficient R2> 0,998, slice $b$ is less than $2 \%$, and that confirms the good linearity of our calibration curve.
The column temperature was $90 \cdot \mathrm{C}$, a flow of a mobile phase was $1 \mathrm{ml} / \mathrm{min}$. The mobile phase is a pure deionized water which is also an advantage of this method because water is available, inexpensive and does not adversely affect health, unlike many organic solvents. Standard solutions were filtered and injected. The retention time of ethanol was at about the 12,6 minute. Every standard injected three times at least. We solved samples with water, then filtered and injected into device two times at least.

HPLC liquid chromatography system includes: injector (loop $20 \mathrm{ul}$ ), pump (Waters 600E System Controller Millipore, Millipore manufacturer 4883 Waters Chromatography Division USA), pre-column (filter 0,2 to $0.5 \mathrm{um}$ ), column ( $\mathrm{CH}$ Polyspher $\mathrm{CA}$, type SC1011, size: $8,0 \mathrm{~mm} \times 300 \mathrm{mmL}$, Machery Nagel), column heater (model: SFD, factory number 95030, manufacturer of Germany), refract metric detector (Waters 410, Millipore Corporation manufacturer of Waters, Chromatography USA, type M410); Standard of ethanol (99.9\% purity Merck KgaA S4271, Darmstadt, Germany); filter for sample and standard ( CA 0.45 um Filter- lab).

\section{RESULTS AND DISCUSSION}

We analyzed 7 different types of syrups (Figure 1 and Figure 2). Content of ethanol was from $<0,05 \%$ to $28,35 \%$. We analyzed 76 syrups and $67 \%$ of them did not have ethanol on a declaration. $8 \%$ of syrups with ethanol declaration, did not have an amount of ethanol according to their declaration. Also $66 \%$ of all tested syrups had alcohol higher than $1,2 \%$ [12]. The European Union (EU) requires the declaration of the alcohol content of beverages containing more than $1,2 \%$ volume of alcohol. This limit is inadequate for many groups wishing to avoid alcohol: children, people of certain religious faiths, violence users, etc. [8].

The concentration of ethanol, in one herbal syrup, made by the same manufacturer, was analyzed between the 7-year long period 20072014. are presented in Table 1. It has been found that different concentrations of ethanol were present in different batches of the syrup despite using the same technology as illustrated in Figure 3 and Figure 4. According to this for each batch of ethanol we had to determine the concentration of ethanol, and declare it. The information given on the label is primarily allowed to a consumer. Labeling should allow consumer to judge a product's contents, quality use characteristics and nutritional value [8].

Table 1. The concentration of ethanol in the one herbal syrup between 7 years

\begin{tabular}{|c|c|}
\hline Year & Concentration of ethanol ( \%) \\
\hline 2007 & 2.5 \\
\hline 2008 & 0.6 \\
\hline 2009 & 2.0 \\
\hline 2012 & 1.27 \\
\hline 2013 & 0.15 \\
\hline 2014 & 0.95 \\
\hline
\end{tabular}


Our results show that the concentration of ethanol in medical and Hedera helicis syrup type was not higher than $1,2 \%$. Also, we can say that herbal mix, Althaea officinalis and Primula veris syrup type, had a significant number of syrups, with the percentage of ethanol higher than 1,2\% in relation to all analyzed syrups. This can be seen below in Figure 5.

\section{CONCLUSIONS}

Through analysis of 76 dietary products by HPLC with refractometer detector and carbohydrate column we found the presence of ethanol in the

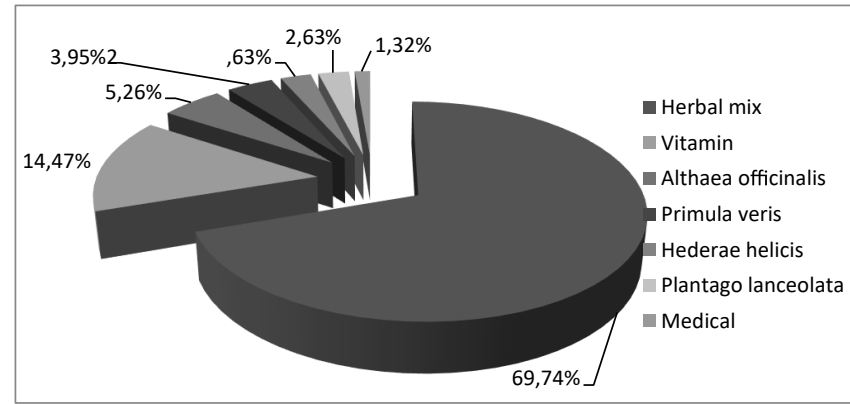

Figure 1.The different types (\%) of all analyzed syrups - the most of them $67 \%$ were herbal mixtures

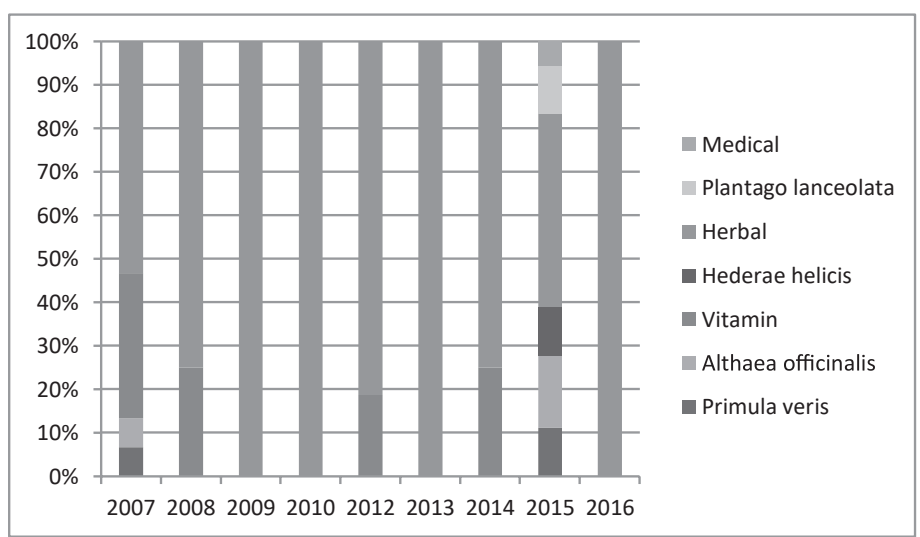

Figure 2.The different types of analyzed syrups into years

2007-Primula veris 6,67\%, Althaea officinalis 6,67\%, Vitamin 33,33\%, Herbal mix 53,33\%

2008-Vitamin type 25\%, Herbal mix 75\%

2012 - Vitamin type $18,75 \%$, Herbal mix $81,25 \%$

2014-Vitamin type 25\%, Herbal mix 75\%

2015 -Medical 5,55\%, Primula veris $11,11 \%$, Hederae helicis $11,11 \%$, Plantago lanceolata $11,11 \%$, Althaea officinalis $16,67 \%$, Herbal mix $44,44 \%$ 2009,2010,2013,2016-Herbal mix only most of the analyzed syrup and $66 \%$ of them had a concentration of ethanol more than $1,2 \%$. The effect of ethanol on the liver, CNS and its influence on the combination with other drugs, is well known, therefore it is necessary to declare its concentration-on the package of syrups. People that most often consume these products are older people and children who are more vulnerable and more prone to hypersensitivity reactions and other unwanted reactions. Also regulations about labeling and declaring in our country are to declare all ingredients of the product and it has been found in our study that $67 \%$ of the analyzed syrup did not have the amount of ethanol declared, which is a significant percentage.

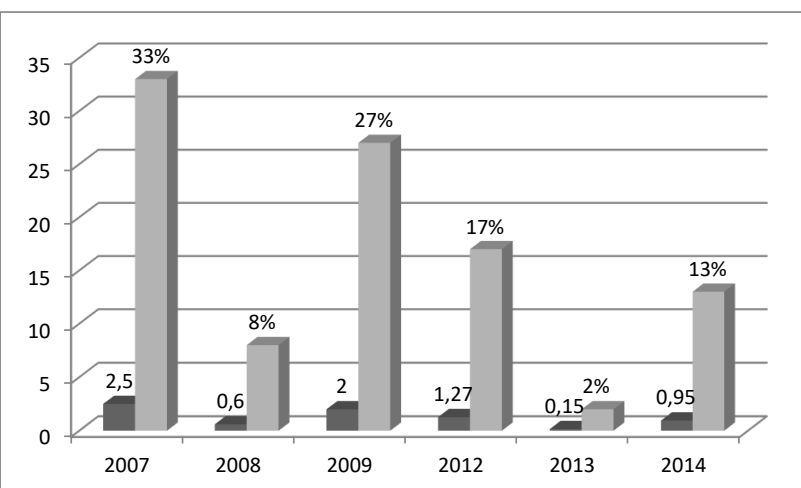

Figure 3. The Concentration of ethanol (\%) in the one herbal syrup between 2007-2014.

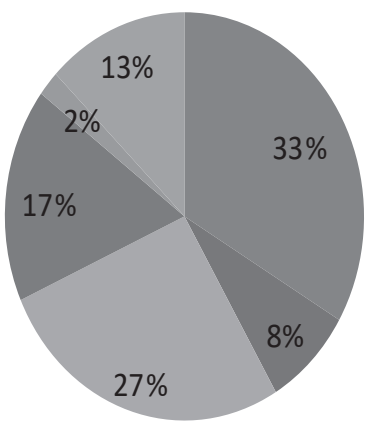

2007

Figure 4. The Concentration of ethanol (\%) in the one herbal syrup between 2007-2014.

-huge statistic difference in $\%$ of ethanol in different batches of the syrup

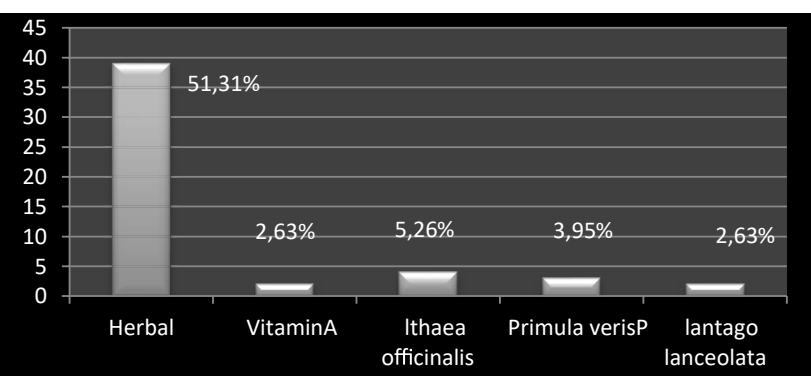

Figure 5. The percentage of syrup that had concentration of ethanol $>1,2$ 


\section{REFERENCES}

1. Connors GJ, Maisto SA. Effects of alcohol instructions and consumption rate on motor performance. J Stud Alcohol 1980; 41:509-17.

2. Anderson C. Ion Chromatography: A New Technique for Clinical Chemistry. Clin Chem 1976; 22(9):1424-6.

3. Medenica M, Malešev D. Hromatografija. U: Medenica M, Malešev D, ured. Eksperimentalna fizička hemija.Beograd: Farmaceutski fakultet, izdanje 1998: 239-52.

4. Karch SB. Drug abuse Handbook. San Francisco: CRC Press; 1998; 322-8.

5. Fagan D, Tiplady B, Scott DB. Effects of ethanol on psychomotor performance. $\mathrm{Br}]$ Anaesth 1987; 59(8): 961-5.

6. James SF, Douglas TGj. Ion Chromatography. In : James SF, Douglas $\mathrm{TGj}$, eds. Ion Chromatography . Weinheim : WILEY-VCH Verlag GmbH \& Co. KGaA, fourh edition 2009: $1-17$.

7. Hanson DJ. Historical evolution of alcohol consumption in society. In: Boyle $\mathrm{P}$, Boffeta $\mathrm{P}$ Lowenfels AB, Burns $\mathrm{H}$, Brawley O, Zatonski W et al., eds. Alcohol: Science, Policy and Public Health. Oxford: Oxford University Press,first edition 2013: 3-10.
8. Kjelkevik R. Food Labelling. Copenhagen: TemaNord; 1998; 9-42.

9. Onuki S, Koziel JA, Leeuwen J, Jenks WS.; Grewell DA; Cai L. Ethanol production, purification, and analysis techniques: a review. Agricultural and Biosystems Engineering Conference Proceedings and Presentations "Asabe Annual International Meeting", Rhode Island 2008;68.

10. Over-the-Counter Drug Products intended for oral ingestion that contain alcohol. FDA. Fed Reg 1993;58:202.

11. Pharmaceutical excipients, an overview including considerations for paediatric dosing. WHO. Tech Rep Ser 2010:167.

12. Pravilnik o deklarisanju, označavanju i reklamiranju hrane. Službeni glasnik RS, Beograd 2013;8:3-4.

13. Pruitt AW, Anyan WR, Hill RM, Kauffman RE, Mofenson $\mathrm{HC}$, Rumack $\mathrm{BH}$ et al. Ethanol in Liquid Preparations Intended for Children. Pediatrics $1984 ; 73: 405-7$.

14. Sharma BK. Liqiud chromatography. In: Sharma M, Sharma A,eds. Chromatography. India: Prakashan Media, first edition 1993: 6895.

15. Shukla SD, Lim RW. Epigenetic Effects of Ethanol on the Liver and Gastrointestinal System. J NIAAA 2013; 35:47-55.

\section{Određivanje etanola u dijetetskim suplementima tipa sirupa}

Marina Perunicic Lucici*,

Zorica Basic ${ }^{1}$,

Brižita Đorđević ${ }^{2}$

Bojana Vidovićz
${ }^{1}$ Vojno medicinska Akademija (VMA), Crnotravska 17, 11000 Beograd, Srbija ${ }^{2}$ Farmaceutski Fakultet - Univerzitet u Beogradu, Vojvode Stepe 450, 11000 Beograd, Srbija

Kratak sadržaj: Dijetetski suplementi su namenjeni dopuni normalne ishrane i predstavljaju koncentrovane izvore vitamina, minerala i drugih supstanci sa hranljivim i fiziološkim efektom. Zbog velike upotrebe dijetetskih preparata, koji često sadrže etanol, moraju se edukovati zdravstveni radnici, kao i potrošači koji ih konzumiraju, kako bi upotreba dijetetskih suplemenata postala sigurna, kontrolisana i racionalna. Etanol se koristi za ekstrakcije, $i$ takodje je važan kao stabilizator u velikom broju dijetetskih suplemenata u obliku sirupa. Zbog toga, veliki broj dijetetskih proizvoda sadrži etanol, a često se dešava da nije ni deklarisan. Još jedan problem je $i$ činjenica da potrošači koji čitaju deklaraciju ovih proizvoda ne mogu da zaključe da je etanol prisutan. Takođe, neki od ovih sirupa se mogu naručiti putem interneta, bez informacije o sadržaju etanola, što je zabrinjavajuće. Osim toga, neki sirupi sadrže istu koncentraciju etanola, kao što je to $i$ u alkoholnim pićima. Koristili smo tečnu hromatografiju, refraktometrijski detektor, ugljeno-hidratnu kolonu, temperaturu $90^{\circ} \mathrm{C}$, za detekciju etanola u dijetetskim suplementima, tipa sirupa, tokom 2007 do 2016.godine. Zatim smo određivali koncentraciju etanola eksternom standardnom metodom. Koncentracija etanola se kretala u opsegu od $<0,05 \%$ do $28,35 \%$. Od 76 analiziranih sirupa 67\% nije imalo deklarisan etanol. $8 \%$ od sirupa sa deklarisanim etanolom, nije imalo istu koncentraciju kao što je deklarisano. Takodje, 66\% od svih analiziranih sirupa je imalo alkohol veći od $1,2 \%$ [12].

Sirupi se tradicionalno koriste u našoj zemlji, a često $i$ u kombinaciji sa drugim lekovima, što može izazvati različite neželjene reakcije.

Ključne reči: etanol, HPLC, suplementi, deklarisanje 